\title{
PENGALAMAN RESPON KLIEN DIABETES MELLITUS TIPE 2 DI KELURAHAN SRENGSENG SAWAH JAKARTA SELATAN
}

\author{
Rusdianingseh \\ Universitas Nahdlatul Ulama Surabaya \\ Email: rusdia@unusa.ac.id
}

\begin{abstract}
Abstrak
Penelitian ini bertujuan untuk mengetahui arti dan makna pengalaman respon klien dalam mengendalikan penyakitnya. Desain penelitian ini menggunakan fenomenologi deskriptif. Data dikumpulkan melalui deep interview atau wawancara mendalam. Partisipan dalam penelitian ini adalah klien diabetes mellitus tipe 2 sejak minimal 2 tahun terakhir. Data yang dikumpulkan berupa rekaman wawancara dan catatan lapangan. Hasil wawancara dibuat transkrip verbatim dan dianalisis menggunakan metode Colaizzi. Penelitian mengidentifikasi 2 tema yaitu respon fisik terhadap DM dan respon psikososial terhadap DM. Penelitian ini merekomendasikan perlunya program peningkatan pengetahuan dan keterampilan klien diabetes mellitus tipe 2 dalam perawatan respon fisik dan psikososial yang dihadapi.
\end{abstract}

Kata kunci: Pengalaman, DM tipe 2, Respon

\begin{abstract}
This study aims to determine the meaning of the client's response experience in controlling the disease. The design of this study uses descriptive phenomenology. Data is collected through in-depth interviews. Participants in this study were type 2 diabetes mellitus clients since at least the last 2 years suffering type 2 diabetes mellitus. Data collected in the form of interview records and field notes. Interview results were made verbatim transcripts and analyzed using the Colaizzi method. The study identified 2 themes namely physical response to DM and psychosocial response to DM. This study recommends the need for a program to increase the knowledge and skills of type 2 diabetes mellitus clients in the treatment of physical and psychosocial responses faced.
\end{abstract}

Keywords: Experience, Type 2 DM, Response 


\section{PENDAHULUAN}

Populasi klien diabetes mellitus meningkat dari tahun ke tahun. Berdasarkan data WHO bahwa saat ini di seluruh dunia terdapat 346 juta klien diabetes mellitus, dan $80 \%$ terjadi di negara berkembang. Diperkirakan akan meningkat menjadi dua kali lipat pada tahun 2030 (WHO, 2013). Internasional Diabetes Federation memperkirakan sekurang-kurangnya 1 dari 10 orang dewasa akan menderita diabetes mellitus tipe 2 pada tahun 2030. Jumlah tersebut meningkat dari data tahun 2013 yang bahwa bahwa 1 dari 13 orang dewasa menderita diabetes mellitus terutama tipe 2 (IDF, 2012).

Penderiita Diabetes mellitus tipe 2 di Indonesia juga terus mengalami peningkatan sampai dengan angka 8,4 juta jiwa pada tahun 2013, yang artinya 1 dari 40 penduduk menderita diabetes mellitus dan angka ini diprediksi akan terus meningkat melebihi 21,3 juta jiwa pada tahun 2030.

Berdasarkan hasil skrining diabetes mellitus di RW 01 Srengseng Sawah, didapatkan 35 klien diabetes mellitus tipe 2,. Hasil kuesioner 58\% klien tidak mengikuti program penatalaksanaan dengan beberapa alasan. Perawatan dengan pengobatan tradisional juga masih dilakukan tanpa monitoring kadar gula darah.

Menurut salah satu kader kesehatan bahwa program puskesmas terkait diabetes meelitus sudah pernah dilaksanakan, seperti Posbindu. Namun jumlah penderita diabetes mellitus masih belum berkurang, bahkan meningkat.

\section{METODE PENELITIAN}

Penelitian ini menggunakan metode penelitian kualitatif. Penelitian kualitatif merupakan pendekatan yang berfokus pada pemahaman tentang fenomena dan seting sosial. Penelitian ini difokuskan melaui proses eksplorasi dan interaksi komunikatif dengan pengakjian yang sistematik, lebih mendalam dan bermakna kepada partisipan mengenai pengalamannya dalam menghadapi respon yang muncul pada penyakit diabetes mellitus tipe 2 .

Pendekatan kualitatif yang digunakan adalah fenomenologi deskriptif. Fenomenologi deskriptif secara langsung mengeksplorasi, menganalisis dan mendiskripsikan fenomena, menstimulasi persepsi pengalaman hidup secara lebih kaya, lebih mendalam dan lebih jelas dari suatu pengalaman.

Teknik pengambilan partisipan yang digunakan adalah purposive sampling. Partisipan dalam penelitian ini sebanyak tujuh partisipan yang sesuai dengan kriteria inklusi, yaitu klien diabetes mellitus tipe 2 tanpa komplikasi yang tinggal dengan keluarganya, berusia di atas 21 tahun sampai 60 tahun, dapat berkomunikasi bahasa Indonesia dengan baik dan bersedia menceritakan pengalamannya terkait respon penyakit diabetes mellitus yang dialaminya serta bersedia menjadi partisipan penelitian ini.

Data penelitian ini diambil melalui wawancara mendalam untuk mendapatkan data pengalaman respon klien terhadap penyakit DM tipe 2. Data hasil wawancara dibuat verbatim dan divalidasi kembali. Wawancara mendalam dilakukan tidak lebih dari 60 menit. Tempat 
dan waktu wawancara ditetapkan sesuai permintaan partisipan, yaitu di rumah masing-masing partisipan pada waktu pagi dan sore hari.

\section{HASIL PENELITIAN}

Hasil penelitian ini menjelaskan uraian tentang respon patisipan diabetes mellitus tipe 2 yang terlibat dalam penelitian dan analisis tematik tentang pengalaman respon klien DM tipe 2.

\section{Karakteristik Partisipan}

Penelitian ini melibatkan tujuh partisipan penderita DM tipe 2. Penjelasan pada partisipan ketujuh sudah mencapai saturasi yaitu terjadi pengulangan jawaban dan tujuan penelitian sudah tercapai. Partisipan bervariasi menurut usia, yaitu termudah berusia 35 tahun dan tertua berusia 58 tahun. Ketujuh partisipan tersebut terdiri dari dua orang lakilaki dan lima orang perempuan, dengan satu orang berstatus janda dan enam orang berstatus menikah. Pendidikan partisipan terdiri dari enam orang tamat SMA dan satu orang tamat SMP. Pekerjaan partisipan terbagi menjadi lima orang sebagai ibu rumah tangga dan dua orang adalah pensiunan. Lama penderita DM tipe 2 bervariasi, minimal 3 tahun sampai 10 tahun. Dari keseluruhan partisipan, sebanyak empat orang menyatakan pernah di rawat rumah sakit akibat kadar gula darah yang terlalu tinggi.

\section{Hasil Analisis Penelitian}

Mengacu pada 5 (lima) tujuan penelitian, maka terjawab dengan dua tema yang selanjutnya akan disajikan sesuai dengan tujuan khusus penelitian.

\section{Pemahaman tentang DM}

Pemahaman partisipan tentang pengertian, penyebab, tanda dan gejala, akibat DM masih belum tepat. Hal tersebut tergambar dari pernyataan sebagai berikut:

"Itu penyakit keturunan bu...bapak saya juga punya kencing manis, jadi ya pantesan saya juga" (P7)

"Sakit gula ini dibawa sampai mati mbak, gak akan bisa sembuh katanya" (P4)

\section{Respon fisik terhadap DM}

Hasil penelitian menjelaskan bahwa sebagian partisipan dapat mengenali tanda dan gejala terjadinya peningkatan dan penurunan kadar gula darah. Partisipan merespon gejala-gejala tersebut dengan cara yang berbedabeda, baik secara fisik maupun psikis.Tiap individu mempunyai kepekaan yang berbeda terhadap perubahan yang dirasakannya. Hal tersebut tergambar dari pernyataan sebagai berikut:

"Saya uda bisa merasakan kalo gula saya tinggi ya lemes badan, gak bertenaga...malas mau ngapa-ngapain...duduk aja kayak gini” (P1)

"... rasanya mata ini berat banget untuk buka mata, lemes juga, pasti gula naik", (P4)

"Perna sekali ngedrop..rasanya kayak mau mati, lemes lemes banget pokoknya, antara sadar 
dan gak waktu itu, badan uda gak bisa digerakin" (P4)

\section{Respon psikososial terhadap DM}

Respon psikologis yang teridentifikasi dalam penelitian ini meliputi tahap denial, bergaining dan acceptance. Sedangkan respon social terjadi perubahan dalam kegiatan social yaitu kurang aktif lagi sejak menderita DM tipe 2. Hal tersebut tergambar dalam pernyataan partisipan sebagai berikut:

"Awal tau kena sakit gula, kaget sih tapi masak iya, gak percaya deh, kapan-kapan periksa lagi aja deh" (P4)

"Saya cuma takut jatuh terus gak ada yang tolongin, kan sendiri di rumah, anak-anak pada kerja" (P1)

"Pasrah aja sama Allah, tapi tetap usah untuk sembuh" (P7)

"Saya ikut kor di gereja, karna sejak kena gula kan saya cepet lemes, saya tinggalin jadinya" (P1).

\section{PEMBAHASAN}

\section{Pemahaman tentang DM}

Hasil penelitian ini mengidentifikasi bahwa pemahaman gejala awal yang dirasakan partisipan terdiri dari gejala utama dan gejala lain. Gejala utama yang dirasakan adalah mudah lapar, mudah haus, sering kencing. Gejala lain yang dirasakan adalah penurunan berat badan, mudah mengantuk, badan lemas, dan luka kaki lama sembuh sembuh. Partisipan lebih mengenali gejala lain dibandingkan gejala klasik berupa cepat lapar, cepat haus, dan sering kencing sebagai tanda awal penyakit diabetes. Penelitian Black dan Hawks (2014) menjelaskan bahwa manifestasi diabetes melitus saat didiagnosis yaitu peningkatan frekuensi buang air kecil (poliuri), peningkatan rasa haus dan minum (polidipsi), dan peningkatan makan (polifagi). Poliuri, polidipsi, dan polifagi sering dirujuk sebagai gejala klasik diabetes melitus. Gejala lain yaitu penurunan berat badan, pandangan kabur berulang, pruritus, infeksi kulit, vaginitis, ketonuria, lemah, letih, pusing, dan bahkan sering asimtomatik.

Pengertian diabetes sebagai penyakit keturunan sebagaimana pernyataan partisipan dalam penelitian ini belum sepenuhnya tepat. Keturunan merupakan salah faktor risiko terjadinya diabetes mellitus. Faktor keturunan/genetik ini berkaitan dengan riwayat keluarga dengan diabetes mellitus tipe 2. Anggota keluarga yang lain kemungkinan lebih besar terserang diabetes mellitus dibanding keluarga yang tidak memiliki riwayat diabetes mellitus. Penelitian yang dilakukan oleh Bianco, Pomara, Raccuglia, Bellafiore, dan Battaglia (2013) menunjukkan adanya hubungan signifikan positif $(\mathrm{p}<0.05)$ pada klien diabetes mellitus tipe 2 dengan riwayat keluarga diabetes mellitus, dibandingkan keluarga tanpa riwayat diabetes mellitus. Perbandingan keluarga yang mempunyai riwayat diabetes mellitus dengan keluarga sehat yang tidak memiliki diabetes mellitus mencapai $5,33 \%$ dan $8,33 \%$ bila dibandingkan dengan keluarga sehat yang memperlihatkan angka hanya $1,96 \%$. 


\section{Respon Fisik terhadap DM}

Hasil penelitian menjelaskan bahwa sebagian partisipan dapat mengenali tanda dan gejala peningkatan, penurunan dan normalnya kadar gula darah. Partisipan merespon gejal-gejala tersebut dengan cara yang berbedabeda, baik secara fisik maupun psikis.tiap individu mempunyai kepekaan yang berbeda terhadap perubahan yang dirasakannya.

Respon fisik saat gula darah meningkat dijelaskan oleh partisipan dengan adanya lemas, mudah mengantuk, kaki terasa kebal/kesemutan, pandangan kabur, mudah lapar dan banyak kencing. Tanda dan gejala di atas sesuai dengan penelitian Keuer dan Lausch (2006) melaui studi fenomenolgi terhadap 12 partisipan yang berusia 50 sampai 62 tahun dengan penyakit diabetes mellitus tipe 2 di bagian selatan Texas ditemukan adanya tanda dan gejala yang dominan dirasakan yaitu peningkatan berkemih, pusing,mengantuk, peningkatan rasa haus, lapar dan kelemahan.

\section{Respon Psikososial}

Respon psikologis partisipan dalam penelitian ini sebagai respon tahap kehilangan, sesuai dengan teori yang dikemukakan oleh KublerRoss, meliputi pengingkaran (denial), tawar-menawar, depresi dan pener. Setiap partisipan tidak sama dalam melalui proses tersebut. Dalam penelitian ini, proses kehilangan yang ditunjukkan partisipan, tidak semuanya muncul sesuai teori di atas. Ada yang bisa langsung mencapai tahap penerimaan, ada yang sangat lama sampai bertahun-tahun untuk akhirnya dapat menerima penyakit DM tipe 2 yang dideritanya. Tahap kehilangan yang dialami partisipan DM tipe 2 dalam penelitian ini meliputi denial, bargaining dan acceptance. Namun peneliti tidak bisa memastikan berapa lama waktu yang dibutuhkan partisipan untuk sampai pada tahap penerimaan, karena lamanya waktu sakit yang dialami partisipan yaitu lebih dari 2 tahun menderita DM tipe 2.

\section{SIMPULAN}

Peneliti menyimpulkan adanya makna dan arti kurang optimalnya respon pengendalian respon yang muncul pada partisipan DM tipe 2 di Srengseng Sawah Jakarta Selatan.

Kurangnya pemahaman partisipan tentang diabetes melitus sehingga mempengaruhi pengendalian DM. Kurangnya keterampilan partisipan dalam menghadapi respon yang muncul terkait penyakitnya. Sehingga perlu adanya program peningkatan pengetahuan dan keterampilan klien diabetes mellitus tipe 2 dalam perawatan respon fisik dan psikososial yang dihadapi. Serta program perawat kesehatan masyarakat yang dapat membina langsung kesehatan keluarga dan msyarakat khususnya penderita diabetes mellitus tipe 2 .

\section{DAFTAR PUSTAKA}

Bhattacharya \& Gauri. (2012). Self Management of Type 2 Diabetes Among African-Americans in The rkansas Delta: A Strengths Perspective in Social Culture 
Context. Journal of Health

Care, 23(2012):161-178.

Brunner, L.S., \& Suddart, D.S.

(2009). Textbook of Medical

Surgical Nursing. Philadelphia:

Lippincott Wiliams \& Wilkins.

Cresswell, J.W. (2010). Research Design: Qualitative, Quantitative, and Mixed Methode Approach. Thirth Edition. California: SAGE Publication.

Departemen Kesehatan RI. (2013). Diabetes Mellitus penyebab kematian nomer enam di Dunia.

http://www.depkes.go.id/artic le/print $/ 2383 / \mathrm{htm}$.

Dinas Kesehatan Kota Depok. (2013). Profil Kesehatan Kota Depok Tahun 2013. Kota Depok.

Friedman, M.M., Bowden, V.R. \& Jones, E.G. (2003). Family Nursing: Research, Theory, \& Practice. New Jersey: Pearson Education, Inc.

International of diabetic Federation (IDF) Diabetes Atlas. (2012). New Estimates for 2012 of Diabetes Prevalence, Mortality, and Healthcare Expenditures. http://www.idf.org/diabetesat las. Diakses $10 \quad$ Februari 2015. 